\title{
Effects of Employee Engagement on Customer Responses - Examining the Mediating Role of Customer Engagement
}

\author{
Rabbanee, F.K. and Ramaseshan, B. and Vyravene, R.
}

\begin{abstract}
Drawing on emotional contagion theory, this study offers an integrated framework showing the effects of employee engagement (EE) on customer engagement (CE), repeat purchase and word-of-mouth (WOM). The data were collected from 65 employees and 352 customers of 28 retail stores using two separate survey instruments. A dyadic data set was created by matching customer data with the employee data corresponding to each store. The findings reveal that two key facets of $\mathrm{EE}$ - dedication and absorption - positively influence $\mathrm{CE}$, which eventually influences WOM and repeat purchase. In line with balance theory, CE is found to fully mediate the effects of absorption on WOM and repeat purchase. Furthermore, employee length of service (ELS) is found to moderate the absorption on CE effects. Thus, the findings extend emotional contagion theory and balance theory by providing empirical evidence supporting the differential effects of the facets of EE on CE en route to WOM and repeat purchase.
\end{abstract}

Keywords: Employee engagement, customer engagement, employee length of service, repeat purchase

\section{Introduction}

Employee engagement (EE) and customer engagement $(\mathrm{CE})$ have received considerable academic interest over the years. Defined as a positive, fulfilling, work related state of mind, EE is characterised by vigour, dedication and absorption (Schaufeli et al., 2002). It creates employee psychological capital (Barnes et al., 2014) which, in turn, leads to customer outcomes such as customer satisfaction and loyalty (Myrden and Kelloway, 2015). A psychological process comprising cognitive and emotional aspects (Bowden, 2009), CE is related to customer-firm or customer-brand interaction dynamics (Brodie et al., 2011). While several studies have examined the effects of EE and CE on firm performance independently, a paucity of studies has examined the simultaneous effects of $\mathrm{EE}$ and $\mathrm{CE}$ on firm performance. 
Specifically, examinations of the intervening role of CE in the relationship between EE and firm performance are almost non-existent. It is important to examine the intervening effects of $\mathrm{CE}$ on the link between EE and firm performance, as employees play a significant role in attracting customer attention and interacting with them, thus contributing to customers' perceptions about the firm and their corresponding responses (Sirianni et al., 2013). Merely understanding the independent effects of $\mathrm{EE}$ and $\mathrm{CE}$ on firm performance may not be adequate for gaining meaningful insights into the role of $\mathrm{EE}$ and $\mathrm{CE}$ in achieving firm objectives. Instead, firms should simultaneously focus on both EE and CE by establishing a strategic and collaborative link between engaged employees and engaged customers to achieve favourable customer responses and long-term growth. This linkage creates a more accurate research model, makes the interpretation of results more robust and contributes to relevant theory. In addition, the most rigorous and widely accepted conceptualisation of EE (Schaufeli et al., 2002, p. 74) encompasses three distinct components: vigour, dedication and absorption. As EE is a work-related mindset that influences superior job performance (Britt, 2003), each of its facets vigour, dedication, and absorption - may have a different effect on customer engagement (CE). However, research to date has considered the EE construct predominantly at an aggregate level, thus restricting the understanding of the explicit effects of its key components. Without a deeper insight into the specific effects of each of the three facets of EE on customer responses, the formulated customer engagement strategies that result may be ineffective.

Furthermore, the conceptualisation of EE and CE in the sole study (Kumar and Pansari, 2016) that investigated their simultaneous effects encompasses outcome-focused dimensions, such as satisfaction, loyalty, commitment, performance, purchase and referral. Despite these useful insights, this conceptualisation largely ignores the psychological aspects of both EE and $\mathrm{CE}$, thus failing to address the underlying mental mechanism relating to employee-customer interactions. Moreover, EE includes both psychological and behavioural facets covering employee passion, enthusiasm and energy at work (Macey and Schneider, 2008). This means 
that employees are psychologically present at work when performing their organisational role (Kahn, 1990, 1992). The psychological conceptualisation of CE includes more persistent and pervasive customer responses covering the cognitive, affective and mental enthusiasm of customer interactions with firms/brands and employees (Bowden, 2009; van Doorn et al., 2010). Recent research argues that CE enhances the experience of the core offering by strengthening psychological connections with the offer (e.g., Harmeling et al., 2017) and engenders a positive psychological attitude towards the firm/brand (de Matos and Rossi, 2008). Thus, mere outcome-based conceptualisation will be inadequate for gaining a useful understanding of the effects of EE on CE leading to firm outcomes. Instead, it is essential to consider the underlying psychological mechanism relating to employee-customer interactions to better understand the inherent employee motivation at work. Thus, EE and CE need to be conceptualised from psychological perspectives to better understand the relationship between goal-directed activities and relevant employee outcomes at work (Kelloway and Barling, 1991). In addition, a longer-tenured employee has more knowledge of his/her clientele and is better able to appropriately judge customer opinions than a recent employee (Pugh et al., 2002). Thus, a longer-tenured employee may have a stronger positive effect on customers, resulting in higher CE which, in turn, may result in repeat purchase. However, prior studies have ignored the potential moderating role of employee length of service (ELS) on the EE-CE relationship. It is therefore necessary to understand the varying effects of EE of long versus short tenured employees on CE.

With regard to the consequences of $\mathrm{EE}$ and $\mathrm{CE}$, prior research on the key consequences of EE has focused on job performance (Rich et al., 2010), burnout tendency (Schaufeli et al., 2002), employee loyalty and attrition (Bhatnagar, 2007), customer satisfaction (Schneider et al., 2009) and attitudinal loyalty (Salanova et al., 2005). The key consequences of CE include contributing to firm performance through cost savings and increased revenue (Harmeling et al., 2017), self-brand connection, and brand usage intent (Hollebeek et al., 2014). Thus, an 
independent focus on the behavioural and psychological outcomes of EE and CE is evident in past studies. In contrast, the current study focuses simultaneously on two unique behavioural and psychological outcomes of EE and CE, namely, repeat purchase and word-of-mouth (WOM). Our reason for including repeat purchase (in addition to WOM) as a dependent variable is the widely accepted belief that behavioural responses, such as repeat purchase, follow from a favourable attitude (Fishbein and Ajzen, 1975). Past research emphasising the behavioural aspects of EE and $\mathrm{CE}$ has largely ignored customer repeat purchase as an outcome variable. In the current study, we consider customers' WOM as the second outcome variable of the EE-CE link, highlighting the psychological conceptualisations of EE and $\mathrm{CE}$ by extending beyond employee behaviour and customer patronage, respectively. Word-of-mouth (WOM) involves social interactions of customers away from their service encounter and consumption from the firm (Akaka et al., 2013); and as the consequent variable of EE and CE, it has received relatively sparse attention in the extant research. Both dependent variables (repeat purchase and WOM) in our model are in line with the theory of customer engagement marketing (Harmeling et al., 2017).

The current study therefore addresses the above-mentioned research gaps with the key purpose of exploring the role of EE on $\mathrm{CE}$, WOM and customer repeat purchase. In doing so, it draws on emotional contagion theory (Hatfield et al., 1994) to examine the EE-CE relationship. Guided by balance theory (Heider, 1958), the study examines the mediating role of $\mathrm{CE}$ on the effects of three facets of EE - vigour, dedication and absorption - on WOM and customer repeat purchase. Furthermore, the current study tests the moderating role of ELS on the links of vigour, dedication, and absorption with CE.

\section{Conceptual Framework}

Our conceptual framework is illustrated in Figure 1, showing that the facets of EE - vigour, dedication and absorption - influence $\mathrm{CE}$ which, in turn, influences customer repeat purchase 
and word-of-mouth (WOM). The conceptual framework also includes the moderating role of employee length of service (ELS) on the links between EE and CE facets. Our conceptual model has its roots in the concept of the service-profit chain (SPC) (Heskett, 1994), which focuses on the relationships between internal (employees) and external (customers) metrics that ultimately explain a firm's performance. The service-profit chain (SPC) links operational investments (such as employee satisfaction) with a firm's performance outcomes via customer satisfaction (Evanschitzky et al., 2012). According to the SPC, several human resource management (HRM) practices positively impact on employee attitudes and behaviours leading to service quality improvements for customers and to improved organisational performance. This suggests a critical link between a firm's employee efforts and its customer outcomes (Schneider and Bowen, 1985). However, EE, an important element of HRM practices, represents an employee's enthusiasm, passion and commitment to their work and to the organisation. It includes employees' willingness to invest their discretionary time and effort to help the employer succeed, with this extending beyond mere satisfaction with the job or basic loyalty to the employer (Macey and Schneider, 2008). Hence instead of the SPC, we draw on emotional contagion theory and balance theory to support the hypotheses shown in Figure 1.

Employee engagement (EE) has been inconsistently conceptualised in the literature, with the focus including both employees' energetic experience of involvement with the job (Leiter et al., 1998) and their work-related mindset (Schaufeli et al., 2002), as well as their attitude and behaviour toward the firm (Kumar and Pansari, 2016). An engaged employee harnesses himself or herself to the work, which is manifested in his/her physical, cognitive and emotional involvement when performing their role with the firm's customers (Kahn, 1990). This reflects the key facets of EE: vigour, dedication and absorption, as supported by Schaufeli et al. (2002). Therefore, our conceptualisation of EE is grounded in organisational psychology research which views EE as contributing to higher employee productivity (Bakker, 2009) and higher organisational outcomes, such as financial turnover (Bakker and Demerouti, 2007). 
Customer engagement (CE) is a psychological state that occurs through interactive and co-creative customer experiences with a brand or a firm (Brodie et al., 2011). Bowden (2009) defined $\mathrm{CE}$ as a psychological process comprising cognitive and emotional aspects. From the behavioural aspect, van Doorn et al. (2010) explained CE as extending beyond the transactions that focus on a customer's behavioural manifestations regarding a brand or firm. In addition, Vivek et al. (2012) conceptualised CE as the representation of customer's interactions and connections with a brand or even with an organisational offering or activity. Guided by Kumar et al. (2010) and Vivek et al. (2014), we define CE as a customer's psychological state that occurs due to interactive customer experiences with a brand or a firm through different channels including online and offline. This is in line with Harmeling et al. (2017)'s theory of customer engagement marketing, in which CE is defined as the customer's voluntary resource contribution to a firm's marketing function, extending beyond financial patronage.

Past literature has considered $\mathrm{CE}$ as a multidimensional construct with its key dimensions covering cognitive, affective and behavioural customer-brand engagement (Hollebeek et al., 2014); and CE aspects including conscious attention, enthused participation and social connection (Vivek et al., 2014). We conceptualise CE as a customer's psychological state (van Doorn et al., 2010) due to his/her focal interactive experiences with a particular firm or brand (Hollebeek, 2011). Influenced by Hollebeek (2011), Hollebeek et al. (2014) and Vivek et al. (2012), we adopt a holistic view in our conceptualisation of CE by arguing that the concept consists of four distinct dimensions: conscious attention, cognitive engagement, affective engagement, and enthused participation. Conscious attention is the customer's level of interest in interacting with the firm, its brand and relevant activities. Cognitive engagement incorporates the customer's experiences and captures participation both within and external to exchange situations between the firm and the customer. Affective engagement incorporates the feelings of potential or current customers towards the firm and its activities through different channels (Vivek et al., 2012). Enthused participation is the degree to which a customer is 
involved in producing or rendering services and thus contributing to the firm's total offerings (Dabholkar, 1990). These dimensions enable the customer to participate in an interactive situation with the firm or its brand which is of common interest to both the firm and the customer (Vivek et al., 2012).

\section{Effect of employee engagement (EE) on customer engagement (CE)}

Engaged employees experience positive work-related feelings, such as happiness and enthusiasm, while performing work tasks (Kahn, 1990; Schaufeli et al., 2002). When experiencing positive affect, people set high goals for a task and expect engagement in a task to yield positive outcomes (Hakanen et al. 2006; Ilies and Judge, 2005). In the context of employee-customer interaction in our study, positive CE results from customers experiencing EE-associated positive inner feelings and emotional states in employees. Prior research has shown that emotions displayed by retail banking employees were found to be positively related to customer affect and customer evaluations of the quality of services received (Pugh, 2001). Therefore, the link between EE and CE can be supported by emotional contagion theory (Hatfield et al., 1994) which states that emotion transfers between interacting individuals. This suggests that emotions displayed by an individual (i.e., an employee) produce a corresponding change in the emotional state of the observer (i.e., the customer). For example, emotions (e.g., humour) displayed by frontline employees influence customers' service encounter evaluations (Chiew et al., 2019). The emotional contagion effect does not take place only within a single dyad of employee and customer; instead, it can span across other employees who work together. As engagement at work focuses on harnessing organisational members themselves to their work roles (Kahn, 1990), when employees are highly engaged, they are likely to share common perceptions about the quality of service in their unit, with the entire unit likely to perform in a similar fashion with all customers. Thus, customers, in turn, feel engaged with employees and report favourable employee performance (Salanova et al., 2005). 
Customers of a firm or a store experience emotional contagion during interactions with employees of that firm/store if they find sincerity in employee efforts and emotions. These relate to employees' energy (vigour), dedication and absorption, which are positively reflected in customers' emotions and contribute to a favourable response. Vigour represents the expression, utilisation and transfer of personal energy and effort into physical, mental and emotional work-related activities (Schaufeli et al., 2002), meaning that the more energetic employees are in their job, the better their performance in dealing with customers. Dedication describes the cognitive and affective degree of devotion, mindfulness and pride an employee has in his/her job (Salanova et al., 2005; Schaufeli et al., 2002), reflecting a possible and consequential link to customer-related outcomes. Absorption reflects an employee's complete concentration on his/her job without losing focus due to external distractions (Anaza et al., 2016), indicating that if employees are absorbed in their job, then it is likely they will do well when dealing with customers, with enhanced CE generated. Based on the above discussion, the key facets of EE (vigour, dedication and absorption) at a store level result in employees' displays of emotion which, in turn, are expected to create corresponding changes in the emotional state of customers at the same level, thus influencing their engagement (i.e., CE). Hence, we hypothesise that:

H1a: Employee vigour at a store level positively influences customer engagement.

H1b: Employee dedication at a store level positively influences customer engagement.

H1c: Employee absorption at a store level positively influences customer engagement.

\section{Effect of customer engagement (CE) on repeat purchase and word-of-mouth (WOM)}

Customer engagement (CE), which is conceptualised based on interactions relating to events and activities of a firm or store that involve customers (Vivek et al., 2012), has been found to influence customer loyalty (Thakur, 2016). As mentioned by van Doorn et al. (2010), CE, as a state of mind, influences customers' actual purchases. Bowden (2009) mentioned that CE is a 
psychological process that drives customer loyalty. In addition, Harmeling et al. (2017), in their theory of customer engagement marketing, mentioned that CE positively contributes to firm revenue through the purchases made and the costs saved. These points lead to our second hypothesis that $\mathrm{CE}$ at a store positively influences customer repeat purchase at that store:

H2a: Customer engagement (CE) at a store level positively influences customer repeat purchase at that store.

Past studies indicate that $\mathrm{CE}$ occurs through interaction with customers which, in turn, influences their attitude and behaviours (Dessart et al., 2015; Mollen and Wilson, 2010). In view of the service ecosystem, word-of-mouth (WOM) involves social interactions of customers that extend beyond their actual service encounters and the consumption of the respective services offered by the firm (Akaka et al., 2013). Customers' social interactions may take place both online and offline. Extant research found empirical evidence that CE influences WOM in the online context (Zhang et al., 2017; Islam and Rahman, 2016). Vargo and Lusch (2004) argued that, when engaged, customers exhibit intention and behaviours that transcend beyond traditional transaction and consumption. Based on the above points, we posit that $\mathrm{CE}$ at a particular store will influence WOM of customers of that store. Therefore, our next hypothesis is:

$\mathrm{H} 2 \mathrm{~b}$ : Customer engagement (CE) at a store level positively influences word-of-mouth of customers of that store.

\section{Mediating role of customer engagement (CE)}

$\mathrm{H} 1 \mathrm{a}, \mathrm{H} 1 \mathrm{~b}$ and $\mathrm{H} 1 \mathrm{c}$, and $\mathrm{H} 2 \mathrm{a}$ and $\mathrm{H} 2 \mathrm{~b}$, as discussed above, show a chain of relationships between $\mathrm{EE}, \mathrm{CE}$, repeat purchase and WOM, indicating that $\mathrm{CE}$ may mediate the $\mathrm{EE}$ relationships of a firm/store with customer repeat purchase and WOM of that firm/store. Salanova et al. (2005) found that employee work engagement influenced service climate 
which, in turn, predicted employee performance and then customer loyalty through a full mediation model. Furthermore, the service-profit chain (SPC) shows a causal chain linking employee satisfaction to firm financial performance through mediating constructs such as customer satisfaction and customer loyalty (Anderson and Mittal, 2000; Homburg et al., 2009). As our model reflects a triadic relationship between employees, customers and the firm, we draw on balance theory (Heider, 1958) to support the mediating role of CE in the relationships of EE with WOM and repeat purchase. This theory suggests that individuals strive to maintain a sense of balance in their lives by attempting to reach "a harmonious state, one in which the entities comprising the situation and the feelings about them fit together without stress" (Heider, 1958, p. 180). When a situation is balanced, no tension is felt; hence, conscious thinking need not to occur. On the other hand, an unbalanced situation results in cognitive tension leading to a tendency toward a balanced state over time, by achieving consistency in attitudes/beliefs and expected outcomes between the two interrelated persons. Woodside and Chebat (2001) suggest that balance theory helps to solve the dilemmas of when and how balanced and imbalanced states occur in product and brand purchase situations. A balanced situation occurs in a triad (e.g., employee-customer-product) if all three relationships between the parties involved are positive (Heider, 1958). Mowen and Brown (1981) used balance theory to define the relationships between the triad of cognitive almanacs of a consumer, a celebrity endorser and a product. An endorser will be maximally effective when she/he has a strong relationship with the consumer and also with the product. When a strong positive emotion develops between a consumer and an endorser, the consumer cognitively reorganises a weaker consumer-product link, if any, and eventually perceives the relevant product more favourably (Abelson and Rosenberg, 1958).

In our model, the key components within a triad are: a store employee who is engaged at work and endorses the company or its brand; a customer of that store for whom the employee is responsible; and the customer's repeat purchase and WOM about the firm as the objects (i.e., 
targets to achieve). The triadic relationships between two persons (i.e., employee and customer) and the objects (i.e., repeat purchase and WOM) of a particular store can be either balanced or unbalanced. A relationship system within a triad is balanced if the two persons have the same attitude/belief toward the object. In a balanced triad, as with employees, customers share repeat purchase and/or WOM as their target object as they are engaged with employees. In this situation, all relationships between parties involved in the triad are positive (Heider, 1958). Moreover, as per emotional contagion theory, the positive emotion that transmits from an engaged store employee to the respective customer of the store is likely to induce him/her (i.e., the customer) to be engaged with the employee or the store and, thus, to respond favourably to the product in terms of repeat purchase and spreading WOM about that store/product. This indicates an integration of balance theory with emotional contagion theory. Based on this integration, we posit that $\mathrm{CE}$ mediates the relationships of $\mathrm{EE}$ a particular store with its customers' repeat purchase and WOM. Likewise, in a balanced triad, it is expected that the facets of EE - vigour, dedication and absorption - will stimulate customers of a firm or store to be engaged with employees of that firm or store, which will, in turn, influence customer repeat purchase and WOM of that store. Thus, we hypothesise that:

$\mathrm{H} 3 \mathrm{a}-\mathrm{c}$ : Customer engagement $(\mathrm{CE})$ at a store level mediates the relationships between (a) employee vigour and customer repeat purchase; (b) employee dedication and customer repeat purchase; and (c) employee absorption and customer repeat purchase at that store.

$\mathrm{H} 4 \mathrm{a}-\mathrm{c}$ : Customer engagement $(\mathrm{CE})$ at a store level mediates the relationships between (a) employee vigour and customer word-of-mouth (WOM); (b) employee dedication and customer word-of-mouth (WOM); and (c) employee absorption and customer wordof-mouth (WOM) at that store. 


\section{Moderating role of employee length of service (ELS)}

Employee length of service (ELS) is found to positively influence effective service recovery (de Jong and de Ruyter, 2004). Experienced employees possess the ability to proactively deal with failure situations (Michel et al., 2009). Pugh et al. (2002) mentioned that long-tenured employees know their customers better than their recently hired colleagues. This means that employees who have been with the firm for a longer time become more involved with customers than employees who are less experienced. Dietz et al. (2004) found that the frequency of employee-customer contact moderated the relationship between employees' perspectives on service climate and customer satisfaction. Hence, it is expected that employees who have been with the firm for longer will be more knowledgeable, vigorous and dedicated in dealing with customers, resulting in more effective CE than among shorter-tenured employees. Thus, we infer that ELS positively moderates the effect of EE on CE:

H5a-c: Employee length of service (ELS) positively moderates the effects of employee (a) vigour, (b) dedication and (c) absorption on customer engagement (CE) at the store level.

\section{Control variable - customer relationship age}

Furthermore, past research shows that customers with longer tenure develop more trust toward the service provider (e.g., Bejou et al., 1996), develop greater inertia (Oliver, 1999) and possess higher risk aversion (Gupta, A. et al., 2004), suggesting that longer-tenured customers have a heightened propensity to repurchase from a service provider. Also, longer tenure provides an opportunity for the customer to develop interpersonal bonds with (Gwinner et al., 1998) or dependence on (Bendapudi and Leone, 2003) the service provider. The contextual variable customer relationship age - has thus been included as a control variable to test the robustness of the conceptualisations underlying the CE-repeat purchase and CE-WOM links. 
The hypotheses are shown in a conceptual framework illustrated in Figure 1.

Insert Figure 1 about here

\section{Method}

\section{Samples and procedure}

The study was conducted in the context of services rendered by retail employees in Australia. A sample of 28 retail stores (14 restaurants, 11 department stores, one retail bank branch, one hair salon and one travel agent) was selected for data collection using separate selfadministered survey instruments for employees and customers. Employees were selected through a network acquaintance (Colgate et al., 2007) and then approached to participate in the survey. After collecting data from store employees, customers of the respective store were approached, using convenience sampling, to participate in the study. Responses from a total of 65 employees and 352 customers were used for analysis. The average age of employee respondents was 23 years, with $44.61 \%$ being male and $41.5 \%$ working as full-time employees. The average length of service of employees with the store was 3.1 years. On the other hand, the average age of customers was 29 years, with $53.69 \%$ being male and $53.10 \%$ buying either frequently or always from the store. The average duration of customer tenure was 5.68 years.

\section{Measures}

The scale to measure EE, which comprised the three key dimensions: vigour, dedication and absorption was adapted from Schaufeli et al. (2002). The dimensions of CE: conscious attention, cognitive engagement, affective engagement and enthused participation were measured using items adapted from Vivek et al. (2014) and Hollebeek et al. (2014). Repeat purchase was measured using two items adapted from Maxham and Netemeyer (2002). The items for WOM were adapted from Zeithaml et al. (1996). All items were measured using a 7- 
point Likert scale (ranging from $1=$ strongly disagree to $7=$ strongly agree). The moderating variable (employee length of service [ELS]) and the control variable (customer relationship age) were measured on a single-item ratio scale (Raimondo et al., 2008).

\section{Data Analysis}

We created a dyadic data set by matching employee data for each store with corresponding customer data; and in doing so, we matched customer data with corresponding employee data of the respective store. Structural equation modelling (SEM) using AMOS (version 22.0) was used for analysis of the matched sample data set. Using both employee and customer data simultaneously in a matched data set to test our hypotheses helped to avoid problems arising from the common variance method.

We operationalised $\mathrm{CE}$ as a second-order reflective construct comprising the four dimensions of conscious attention, cognitive engagement, affective engagement, and enthused participation (Bollen and Lennox, 1991). This second-order operationalisation of CE as a construct is in line with the extant literature (e.g., So et al., 2016; Thakur, 2016). The measurement model, with this higher-order factor structure, requires the use of hierarchical confirmatory factor analysis (CFA), for which a well-defined first-order factor measurement model is a prerequisite (Marsh, 1991; So et al., 2016). Hence, our data analysis involved both the first-order measurement model consisting of all scale items corresponding to the $\mathrm{CE}$ dimensions, and a second-order CFA estimated to assess the CE second-order factor structure. We started with exploratory factor analysis (EFA) which revealed that the constructs were unidimensional and that each item loaded highly on the respective construct. The convergent validity of the constructs (including the first-order dimensions of $\mathrm{CE}$ ) was confirmed as the factor loading of all items loaded significantly (at the 0.01 level) onto the expected latent construct (Hair et al., 2010) (see Table 1). The correlations across different constructs (including the first-order dimensions of CE) (see Table 2) were within the acceptable limit, 
thus confirming discriminant validity (Kline, 2015). With the lowest value of construct reliability (CR) of 0.82 for enthused participation (one of the dimensions of $\mathrm{CE}$ ), this suggested adequate internal consistency of the scale items. The minimum average variance extracted (AVE) value was found to be 0.61 for enthused participation, thus demonstrating discriminant validity of the constructs (Fornell and Larcker, 1981). The goodness-of-fit measures for the measurement model showed an acceptable fit with the data $\left(\chi^{2}=1398.87 ; d f=478 ; \chi^{2} / d f=2.93\right.$; RMSEA=0.07; CFI=0.91; NFI=0.86; TLI=0.89; SRMR=0.07), suggesting that the constructs are different from each other.

Insert Table 1 about here

Insert Table 2 about here

\section{Results}

The fit indices of the structural model (Table 3) showed an acceptable fit with the data $\left(\chi^{2}=1455.89 ; d f=485 ; \chi^{2} / d f=3.00 ;\right.$ RMSEA $=0.07 ; \mathrm{CFI}=0.90 ; \mathrm{NFI}=0.86 ; \mathrm{TLI}=0.89 ;$ $\mathrm{SRMR}=0.05)$.

Insert Table 3 about here

As shown in Table 3, all the hypothesised relationships are found to be significant except for H1a. Dedication $(\beta=0.42 ; p<0.05)$ and absorption $(\beta=0.20 ; p<0.05)$ are found to have a significant positive influence on CE explaining $14 \%$ of its variance $\left(r^{2}=0.14\right)$. On the other hand, vigour is not found to significantly influence $\operatorname{CE}(\beta=-0.26 ; p>0.05)$. Furthermore, $\mathrm{CE}$ is found to significantly influence repeat purchase $(\beta=0.70 ; p<0.05)$ and WOM $(\beta=0.84$; $p<0.05)$. The control variable, customer relationship age, is also found to positively influence repeat purchase $(\beta=0.11 ; p<0.05)$ but does not significantly influence WOM $(\beta=-0.07 ; p>0.05)$. 
Both CE and the control variable (relationship age) account for $50 \%$ of the variance of repeat purchase $\left(r^{2}=0.50\right)$ and $72 \%$ of the variance of WOM $\left(r^{2}=0.72\right)$.

With regard to the mediating role of $\mathrm{CE}$ on the links of vigour, dedication and absorption with repeat purchase and WOM (H3a, H3b and H3c, and H4a, H4b and H4c), we examined both the direct effects (from vigour, dedication and absorption to repeat purchase and WOM) and the indirect effects (from vigour, dedication and absorption to repeat purchase and WOM via CE) to check for full or partial mediation (Reimann et al., 2010). The direct effects are found to be insignificant for vigour $(\beta=0.05 ; t=0.33, p>0.05)$, dedication $(\beta=0.06 ; t=0.34$, $p>0.05)$ and absorption $(\beta=-0.13 ; t=-1.60, p>0.05)$ on repeat purchase. The direct effects on WOM are found to be insignificant for vigour $(\beta=0.12 ; t=0.94, p>0.05)$, dedication $(\beta=-0.07$; $t=-0.46, p>0.05)$ and absorption $(\beta=-0.10 ; t=-1.41, p>0.05)$. Furthermore, the indirect effects of $\operatorname{vigour}(\beta=-0.22 ; t=-1.29, p>0.05)$ and dedication $(\beta=0.32 ; t=1.77, p>0.05)$ on repeat purchase via $\mathrm{CE}$ are also insignificant, meaning that $\mathrm{CE}$ has no mediating effect on the links of vigour and dedication with repeat purchase. On the other hand, the indirect effect of absorption $(\beta=0.18 ; t=2.2, p<0.05)$ on repeat purchase via $\mathrm{CE}$ is found to be significant. Hence, CE fully mediates the link of absorption with repeat purchase. In a similar vein, the indirect effects of $\operatorname{vigour}(\beta=-0.27 ; t=-1.26, p>0.05)$ and dedication $(\beta=0.38 ; t=1.74, p>0.05)$ on WOM via $C E$ are also insignificant, meaning that $\mathrm{CE}$ does not have any mediating effect on the links of vigour and dedication with WOM. The indirect effects of absorption $(\beta=0.21 ; t=2.14, p<0.05)$ on WOM via $\mathrm{CE}$ is found to be significant. Hence, $\mathrm{CE}$ fully mediates the link of absorption with WOM; therefore, while $\mathrm{H} 3 \mathrm{c}$ and $\mathrm{H} 4 \mathrm{c}$ are supported, $\mathrm{H} 3 \mathrm{a}, \mathrm{H} 3 \mathrm{~b}, \mathrm{H} 4 \mathrm{a}$ and $\mathrm{H} 4 \mathrm{~b}$ are not supported. The moderating effects of employee length of service (ELS) on the links of vigour, dedication and absorption with $\mathrm{CE}$ (H5a, H5b and $\mathrm{H} 5 \mathrm{c}$ ) were examined by multi-group analysis based on the median-split procedure (Malär et al., 2011) with a median score of ELS of 3.11 years. The nested data set is sufficiently large $(\mathrm{N}=352)$ for the moderating variable, ELS, to be measured as a ratio scale. Hence, in our data set, compensating for any loss of 
power due to the median split, and for collinearity between the moderating variable and other independent variables were not issues. Therefore, dichotomising ELS to examine the group differences ("high" versus "low") was deemed appropriate (Iacobucci et al., 2015). Consistent with the extant literature (e.g., Roy and Rabbanee, 2015), we ran two models based on high ELS value versus low ELS value and compared the chi-square values and degrees of freedom $(d f)$ of the totally free (TF) model (without restricting the paths of the model) with the same values of the fully constrained (FC) model (by restricting all the paths of the model) to test ELS's moderating effect.

The fit indices of the TF model are found to be satisfactory with $\chi^{2}=2751.16 ; d f=970$; $\chi^{2} / d f=2.84 ; \mathrm{RMSEA}=0.07 ; \mathrm{CFI}=0.84 ; \mathrm{TLI}=0.81$ and $\mathrm{NFI}=0.80$. The TF model revealed that with the low ELS value, the links of vigour $(\beta=-0.21 ; t=-0.64, p>0.05)$, dedication $(\beta=0.60$; $t=1.31, p>0.05)$, and absorption $(\beta=-0.18 ; t=-0.82, p>0.05)$ with CE were insignificant. On the other hand, with the high ELS value, the links of vigour $(\beta=-0.61 ; t=-1.77, p>0.05)$ and dedication $(\beta=0.56 ; t=1.71, p>0.05)$ with $\mathrm{CE}$ were found to be insignificant, whereas the effect of absorption $(\beta=0.51 ; t=3.84, p<0.05)$ on $\mathrm{CE}$ was significant.

Again, the fit indices of the FC model fall within somewhat acceptable limits, with $\chi^{2}=3230.89 ; d f=983 ; \chi^{2} / d f=3.28 ; \mathrm{RMSEA}=0.08 ; \mathrm{CFI}=0.80 ; \mathrm{TLI}=0.80$ and $\mathrm{NFI}=0.75$. The differences in the chi-square and degrees of freedom values of the TF and FC models were found to be significant $\left(\Delta \chi^{2}=479.73 ; \Delta d f=13 ; p<0.05\right)$. Therefore, the two models significantly differ from each other. The details of the path coefficients for the low and high ELS values are shown in Tables $4 \mathrm{a}$ and $4 \mathrm{~b}$. These confirm the significant moderating influence of ELS on the link between absorption with $\mathrm{CE}$; thus, while $\mathrm{H} 5 \mathrm{c}$ is supported, $\mathrm{H} 5 \mathrm{a}$ and $\mathrm{H} 5 \mathrm{~b}$ are not supported. 


\section{Discussion and Implications}

This study provides much-needed insights on the relationships between the facets of EE, CE, customer repeat purchase and WOM using data from two distinct sources: employees and customers. The study found that the EE facets of dedication and absorption, but not vigour, positively influence $\mathrm{CE}$ which, in turn, influences customer WOM and repeat purchase. The non-significant impact of vigour on CE indicates that employees do not engage customers merely by being energetic at work; rather they remain dedicated and absorbed at work. Furthermore, $\mathrm{CE}$ is found to mediate the effects of absorption on WOM and repeat purchase. This novel finding indicates that a store with high employee engagement, in terms of absorption, leads to customer repeat purchase and WOM only if the store and its employees engage with their customers. This mediating effect of $\mathrm{CE}$ also underscores the need for firms to focus on both EE and CE simultaneously. We also found a significant moderating impact of ELS on the link between CE and absorption. This means that employees who serve a firm for a longer period become more absorbed in their work, thus contributing more to customer engagement than employees who have served the firm for a shorter period. Moreover, the inclusion of customer relationship age as a control variable shows robustness of our model in conceptualising and testing the EE-CE-repeat purchase and EE-CE-WOM links.

The study findings offer several theoretical contributions. Firstly, the study pinpoints $\mathrm{CE}$, repeat purchase and WOM as consequences of EE, thus identifying EE-CE-repeat purchase and EE-CE-WOM as sequential chains of relationships. In doing so, the study extends the existing engagement literature and emotional contagion theory by showing empirical support for the differential effects of the three facets of $\mathrm{EE}$ on $\mathrm{CE}$ en route to repeat purchase and WOM through a parsimonious model. Secondly, the study shows that CE fully mediates the relationship of absorption with customer responses, such as WOM and repeat purchase. This extends balance theory (Heider, 1958) by focusing on its integration with 
emotional contagion theory. This is done by explaining the EE-CE-repeat purchase and EECE-WOM links as relationship systems, in which EE influences repeat purchase and WOM through CE's mediating effect. This provides evidence to support the prevalence of balanced triads. Thirdly, the current study provides empirical proof of WOM as a consequence of the EE-CE link, supporting EE's and CE's psychological conceptualisations. This further reflects an application of the theory of customer engagement marketing (Harmeling et al., 2017), a theory which emphasises CE as customers' voluntary contribution that extends beyond financial patronage. Thus, the study advances the extant literature through its conceptualisation and measurement of EE and CE drawn from the organisational psychology literature, as opposed to the behavioural outcome-focused conceptualisations of $\mathrm{EE}$ and $\mathrm{CE}$ in prior research (e.g., Kumar and Pansari, 2016). Fourthly, the finding that ELS positively moderates the effects of absorption on $\mathrm{CE}$ is unique and makes an important contribution to the extant literature by suggesting a boundary condition based on which the effects of EE on CE may vary. Finally, unlike many studies in the extant engagement research, the current study used a matched sample dyadic data set to examine the simultaneous effects of EE and CE on repeat purchase and WOM, at both individual and aggregate levels.

Our study offers useful insights for managers. The study findings of the significant effects of dedication and absorption on CE are important for managers as employees may not always feel connected with the respective firm/store for which they work (Mascio and Fatima, 2018). This means that the respective firm/store may have less influence on its employees' work-related decisions; hence, managers should focus more specifically on how to ensure employee dedication and absorption at work. To achieve this purpose, firms should invest resources and adopt specific strategies, such as ensuring an organisational climate supportive of initiative and psychological safety, to engage employees (Rabbanee et al., 2019) so they become dedicated to and absorbed in their work, thus helping them to be proactive in engaging customers. Past research has provided empirical evidence showing that organisational climate 
influences employees' thoughts, feelings and behaviours (Bock et al., 2005); employees' creativity and proactivity (Eldor and Harpaz, 2016); and employee-customer interactions (Clark, 2002). Firms could also facilitate employee dedication and absorption at work by providing organisational support (Rich et al., 2010); job autonomy; support technology (Salanova et al., 2005); and career development opportunities.

The unique finding that $\mathrm{CE}$ mediates the links of employee absorption with repeat purchase and WOM highlights the need for managers to focus on both EE and CE simultaneously. Managers should facilitate an appropriate environment in their store, enabling their employees to adequately engage with their customers. To achieve this purpose, managers could adopt an initiative-enhancing human resource management (HRM) system in the store that promotes and recognises employee initiatives (Hong et al., 2016). Managers should recruit employees with dispositional proactivity and capabilities (Schneider et al., 2000), providing training to improve employees' self-efficacy (Axtell and Parker, 2003) and enhancing their current level of proactivity (Fay and Sonnentag, 2010). These strategies are likely to result in a favourable climate for initiatives in the store, encouraging employees to extend beyond their routine jobs when dealing with customers and, thus, positively affecting customer engagement (Rabbanee et al., 2019) and behavioural responses. Moreover, our mediation finding underscores the need to allocate resources to both EE and CE for customer-based firm performance. Managers should not overlook the role of EE in attaining desired customer responses. As engaged employees are energetic and passionate about their job when dealing with customers, ignoring the role of EE may lead managers to miss an effective way of differentiating their offerings in addition to their core products or services. As past research has found that CE mediates the link between different aspects of product involvement, such as symbolic value and personal interest relating to the product and customer loyalty (Parihar et al., 2019), engaged employees can be the essence of this symbolic value and customers' personal interest in the store and its products. Thus, engaged employees may act as a potential switching 
barrier (Colgate et al., 2007), stimulating positive WOM and behavioural loyalty. Furthermore, our findings underscore the point that managers must pay attention to employee psychology to ensure the quality and competitiveness of their services. As contact employees share collective feelings at their workplace (Salanova et al., 2005), it is important for managers to adopt appropriate steps to engage each employee proactively to avoid the contagion effect from one disengaged employee to others. In addition, the positive moderating role of ELS emphasises that managers should invest resources in employee retention. The study findings indicate that longer-tenured employees are more engaged at work than shorter-tenured employees in their dedication to and absorption in the jobs, with their engagement leading to CE, customer WOM and repeat purchase.

\section{Limitations and Future Research Directions}

Our study has a few limitations. Firstly, it does not focus on drivers of EE, such as training, autonomy, technology (Salanova et al., 2005), job satisfaction, commitment and loyalty (Kumar and Pansari, 2016). Future research should focus on more nuanced employee psychological variables that may drive employee work engagement. Secondly, although our study's empirical evidence showed support for the effect of EE on CE and customer responses, the process should be continuous with a feedback loop of customer behaviour affecting organisational resources allocated to EE enhancement. Hence, future research is warranted to examine these continuous path relationships including the feedback loop. Thirdly, the link between EE and CE can be influenced by other moderators such as culture, as customer engagement behaviour differs between developed and developing markets (Roy et al., 2018). Future research is warranted to test our model in a developing country context. Fourthly, the study focuses on EE as the driver of customer engagement (CE). The extant literature identified other drivers of CE, such as product experience (Harmeling et al., 2017), emotion and satisfaction (Gupta et al., 2018). However, these drivers were beyond the scope of our research. 
Finally, this study is based on a cross-sectional survey design; hence, the reciprocal relationships between employees and customers cannot be fully interpreted causally, an area which future researchers may consider for further exploration. 


\section{References}

Abelson RP and Rosenberg MJ (1958) Symbolic psychologic: A model of attitudinal cognition. Behavioural Science 3: 1-13.

Akaka MA, Vargo SL and Lusch RF (2013) The complexity of context: A service ecosystems approach for international marketing. Journal of Marketing Research 21(4): 1-20.

Anaza NA, Nowlin EL and Wu GJ (2016) Staying engaged on the job: The role of emotional labor, job resources, and customer orientation. European Journal of Marketing 50: $1470-1492$.

Anderson EW and Mittal V (2000) Strengthening the satisfaction-profit chain. Journal of Service Research 3(2): 107-120.

Axtell CM and Parker SK (2003) Promoting role breadth self-efficacy through involvement, work redesign and training. Human Relations 56(1): 113-131.

Bakker AB (2009) Building engagement in the workplace. In Burke RJ and Cooper CL (eds) The Peak Performing Organization. Oxon, UK: Routledge, pp.50-72.

Bakker AB and Demerouti E (2007) The job demands-resources model: State of the art. Journal of Managerial Psychology 22(3): 309-328.

Barnes CD, Collier EJ and Robinson S (2014) Customer delight and work engagement. Journal of Services Marketing 28(5): 380-390.

Bejou D, Wray B and Ingram TN (1996) Determinants of relationship quality: An artificial neural network analysis. Journal of Business Research 36(2): 137-143.

Bendapudi N and Leone RP (2003) Psychological implications of customer participation in coproduction. Journal of Marketing 67(1): 14-28.

Bhatnagar J (2007) Talent management strategy of employee engagement in Indian ITES employees: Key to retention. Employee Relations 29(6): 640-663.

Bock GW, Lee JN, Zmud RW and Kim YG (2005) Behavioural intention formation in knowledge sharing: Examining the roles of extrinsic motivators, social-psychological forces, and organizational climate. MIS Quarterly 29(1): 87-111.

Bollen KA and Lennox R (1991) Conventional wisdom on measurement: A structural equation perspective. Psychological Bulletin 110(2): 305-314. 
Bowden JLH (2009) The process of customer engagement: A conceptual framework. Journal of Marketing Theory \& Practice 17(1): 63-74.

Britt TW (2003) Aspects of identity predict engagement in work under adverse conditions. Self \& Identity 2: 31-45.

Brodie RJ, Hollebeek LD, Jurić B and Ilić A (2011) Customer engagement: Conceptual domain, fundamental propositions, and implications for research. Journal of Service Research 14(3): 252-271.

Chiew TM, Mathies C and Patterson P (2019) The effect of humour usage on customer's service experiences. Australian Journal of Management 44(1): 109-127.

Clark M (2002) The relationship between employees' perceptions of organizational climate and customer retention rates in a major retail bank. Journal of Strategic Marketing 10(2): 93-113.

Colgate M, Tong VTU, Lee CKC and Farley JU (2007) Back from the brink: Why customers stay. Journal of Service Research 9(3): 211-228.

Dabholkar PA (1990) How to improve perceived service quality by improving customer participation. In Dunlap BJ (ed) Development in Marketing Science. Cullowhee, NC: Academy of Marketing Science, pp.483-487.

de Jong A and de Ruyter K (2004) Adaptive versus proactive behavior in service recovery: The role of self-managing teams. Decision Sciences 35(3): 457-491.

de Matos CA and Rossi CAV (2008). Word-of-mouth communications in marketing: A metaanalytic review of the antecedents and moderators. Journal of the Academy of Marketing Science 36(4): 578-596.

Dessart L, Veloutsou C and Morgan-Thomas A (2015) Consumer engagement in online brand communities: A social media perspective. Journal of Product and Brand Management 24(1): 28-42.

Dietz J, Pugh SD and Wiley JW (2004) Service climate effects on customer attitudes: An examination of boundary conditions. Academy of Management Journal 47(1): 81-92.

Eldor L and Harpaz I (2016) A process model of employee engagement: The learning climate and its relationship with extra-role performance behaviors. Journal of Organizational Behavior 37(2): 213-235. 
Evanschitzky H, Wangenheim FV and Wünderlich NV (2012) Perils of managing the service profit chain: The role of time lags and feedback loops. Journal of Retailing 88(3): 356366.

Fay D and Sonnentag S (2010) A look back to move ahead: New directions for research on proactive performance and other discretionary work behaviours. Applied Psychology 59(1): 1-20.

Fishbein M and Ajzen I (1975) Belief, Attitude, Intention and Behavior: An Introduction to Theory and Research. Reading, MA: Addison-Wesley.

Fornell C and Larcker DF (1981) Evaluating structural equation models with unobservable variables and measurement error. Journal of Marketing Research 18(1): 39-50.

Gwinner KP, Gremler DD and Bitner MJ (1998) Relational benefits in services industries: The customer's perspective. Journal of the Academy of Marketing Science 26(2): 101-114.

Gupta A, Su BC and Walter Z (2004) An empirical study of consumer switching from traditional to electronic channels: A purchase-decision process perspective. International Journal of Electronic Commerce 8(3): 131-161.

Gupta S, Pansari A and Kumar V (2018) Global customer engagement. Journal of International Marketing 26(1): 4-29.

Hair JF, Black WC and Babin BJ (2010) Multivariate Data Analysis: A Global Perspective. Upper Saddle River, NJ: Pearson.

Hakanen JJ, Bakker AB and Schaufeli WB (2006) Burnout and work engagement among teachers. Journal of School Psychology 43: 495-513.

Harmeling CM, Moffett JW, Arnold MJ and Carlson BD (2017) Toward a theory of customer engagement marketing. Journal of the Academy of Marketing Science 45(3): 312-335.

Hatfield E, Cacioppo JT and Rapson RL (1994) Emotional contagion. In Cambridge Studies in Emotion and Social Interaction. Cambridge, UK: Cambridge University Press.

Heider F (1958) The Psychology of Interpersonal Relations. New York, NY: John Wiley \& Sons.

Heskett JL, Jones TO, Loveman GW, Sasser WE and Schlesinger LA (1994) Putting the service-profit chain to work. Harvard Business Review (March-April): 164-170. 
Hollebeek LD (2011) Demystifying customer brand engagement: Exploring the loyalty nexus. Journal of Marketing Management 27(7/8): 785-807.

Hollebeek LD, Glynn MS and Brodie RJ (2014) Consumer brand engagement in social media: Conceptualization, scale development and validation. Journal of Interactive Marketing 28(2): 149-165.

Homburg C, Wieseke J and Hoyer WD (2009). Social identity and the service-profit chain. Journal of Marketing 73(2): 38-54.

Hong Y, Liao H, Raub S and Han JH (2016) What it takes to get proactive: An integrative multilevel model of the antecedents of personal initiative. Journal of Applied Psychology 101(5): 687-701.

Iacobucci D, Posavac SS, Kardes FR, Schneider M and Popovich D (2015) Toward a more nuanced understanding of the statistical properties of a median split. Journal of Consumer Psychology 25(4): 652-665.

Ilies R and Judge TA (2005) Goal regulation across time: The effect of feedback and affect. Journal of Applied Psychology 90: 453-467.

Islam JU and Rahman Z (2016) Linking customer engagement to trust and word-of-mouth on Facebook brand communities: An empirical study. Journal of Internet Commerce 5(1): $40-58$.

Kahn WA (1990). Psychological conditions of personal engagement and disengagement at work. Academy of Management Journal 33(4): 692-724.

Kahn WA (1992) To be full there: Psychological presence at work. Human Relations 45: 321349.

Kelloway EK and Barling J (1991) Job characteristics, role stress and mental health. Journal of Occupational and Organizational Psychology 64(4): 291-304.

Kline RB (2015) Principles and Practice of Structural Equation Modelling. New York, NY: Guilford Publications.

Kumar V, Aksoy L, Donkers B, Venkatesan R, Wiesel T and Tillmanns S (2010) Undervalued or overvalued customers: Capturing total customer engagement value. Journal of Service Research 13(3): 297-310. 
Kumar V and Pansari A (2016) Competitive advantage through engagement. Journal of Marketing Research 53(4): 497-514.

Leiter MP, Maslach C and Frame K (1998) Burnout. In The Encyclopaedia of Clinical Psychology.

Macey WH and Schneider B (2008) The meaning of employee engagement. Industrial and Organizational Psychology 1(1): 3-30.

Malär L, Krohmer H, Hoyer WD and Nyffenegger B (2011) Emotional brand attachment and brand personality: The relative importance of the actual and the ideal self. Journal of Marketing 75(4): 35-52.

Marsh HW (1991) Multidimensional students' evaluations of teaching effectiveness: A test of alternative higher-order structures. Journal of Educational Psychology 83(2): 285-296.

Mascio RD and Fatima J (2018) The role of identification in frontline employee decisionmaking. Journal of Retailing and Consumer Services 43: 131-138.

Maxham JG and Netemeyer RG (2002) Modelling customer perceptions of complaint handling over time: The effects of perceived justice on satisfaction and intent. Journal of Retailing 78(4): 239-252.

Michel S, Bowen D and Johnston R (2009) Why service recovery fails. Journal of Service Management 20(3): 253-273.

Mollen A and Wilson H (2010) Engagement, telepresence and interactivity in online consumer experience: Reconciling scholastic and managerial perspectives. Journal of Business Research 63(9): 919-925.

Mowen JC and Brown SW (1981) On explaining and predicting the effectiveness of celebrity endorsers. Advances in Consumer Research 8: 437-441.

Myrden SE and Kelloway EK (2015) Leading to customer loyalty: A daily test of the serviceprofit chain. Journal of Services Marketing 29(6-7): 585-598.

Oliver RL (1999) Whence consumer loyalty? Journal of Marketing 63(Special Issue): 33-44.

Parihar P, Dawra J and Sahay V (2019) The role of customer engagement in the involvementloyalty link. Marketing Intelligence and Planning 37(1): 66-79.

Pugh SD (2001) Service with a smile: Emotional contagion in the service encounter. Academy of Management Journal 44(5): 1018-1027. 
Pugh SD, Dietz J, Wiley JW and Brooks SM (2002) Driving service effectiveness through employee customer linkages. Academy of Management Executive 16(4): 73-84.

Rabbanee FK, Haque MM, Banik S and Islam MM (2019) Managing engagement in an emerging economy service. Journal of Service Theory and Practice 29(5/6): 610-638.

Raimondo MA, Miceli GN and Costabile M. (2008) How relationship age moderates loyalty formation: The increasing effect of relational equity on customer loyalty. Journal of Service Research 11(2): 142-160.

Reimann M, Schilke O and Thomas JS (2010) Customer relationship management and firm performance: The mediating role of business strategy. Journal of the Academy of Marketing Science 38(3): 326-346.

Rich BL, Lepine JA and Crawford ER (2010) Job engagement: Antecedents and effects on job performance. Academy of Management Journal 53(3): 617-635.

Roy R and Rabbanee FK (2015) Antecedents and consequences of self-congruity. European Journal of Marketing 49(3/4): 444-466.

Roy SK, Balaji MS, Soutar G, Lassar WM and Roy R (2018) Customer engagement behavior in individualistic and collectivistic markets. Journal of Business Research 86: 281-290.

Salanova M, Agut S and Peiró JM (2005) Linking organizational resources and work engagement to employee performance and customer loyalty: The mediation of service climate. Journal of Applied Psychology 90(6): 1217-1227.

Schaufeli WB, Salanova M, González-Romá V and Bakker AB (2002) The measurement of engagement and burnout: A two sample confirmatory factor analytic approach. Journal of Happiness Studies 3(1): 71-92.

Schneider B and Bowen DE (1985) Employee and customer perceptions of service in banks: Replication and extension. Journal of Applied Psychology 70: 423-433.

Schneider B, Macey WH, Barbera KM and Martin N (2009) Driving customer satisfaction and financial success through employee engagement. People and Strategy, 32(2): 22-27.

Schneider B, Smith DB and Goldstein HW (2000) Attraction-selection-attrition: Toward a person-environment psychology of organizations. In Walsh WB, Craik KH and Price RH (eds) Person-Environment Psychology: New Directions and Perspectives ( $2^{\text {nd }}$ edn). Mahwah, NJ: Erlbaum, pp.61-85. 
Sirianni NJ, Bitner MJ, Brown SW and Mandel N (2013) Branded service encounters: Strategically aligning employee behavior with the brand positioning. Journal of Marketing 77(6): 108-123.

So KKF, King C, Sparks BA and Wang Y (2016) The role of customer engagement in building consumer loyalty to tourism brands. Journal of Travel Research 55(1): 64-78.

Thakur R (2016) Understanding customer engagement and loyalty: A case of mobile devices for shopping. Journal of Retailing and Consumer Services 32: 151-163.

van Doorn J, Lemon KN, Mittal V, Nass S, Pick D, Pirner P and Verhoef PC (2010) Customer engagement behavior: Theoretical foundations and research directions. Journal of Service Research 13(3): 253-266.

Vargo SL and Lusch RF (2004) Evolving to a new dominant logic for marketing. Journal of Marketing 68(1): 1-17.

Vivek SD, Beatty SE, Dalela V and Morgan RM (2014) A generalized multidimensional scale for measuring customer engagement. Journal of Marketing Theory and Practice 22(4): $401-420$.

Vivek SD, Beatty SE and Morgan RM (2012) Customer engagement: Exploring customer relationships beyond purchase. Journal of Marketing Theory and Practice 20(2): 122146.

Woodside AG and Chebat JC (2001) Updating Heider's balance theory in consumer behavior: A Jewish couple buys a German car and additional buying-consuming transformation stories. Psychology \& Marketing 18(5): 475-495.

Zeithaml VA, Berry LL and Parasuraman A (1996) The behavioural consequences of service quality. Journal of Marketing 60(2): 31-46.

Zhang M, Guo L, Hu M and Liu W (2017) Influence of customer engagement with company social networks on stickiness: Mediating effect of customer value creation. International Journal of Information Management 37(3): 229-240. 
Appendices

Figure 1: Conceptual framework

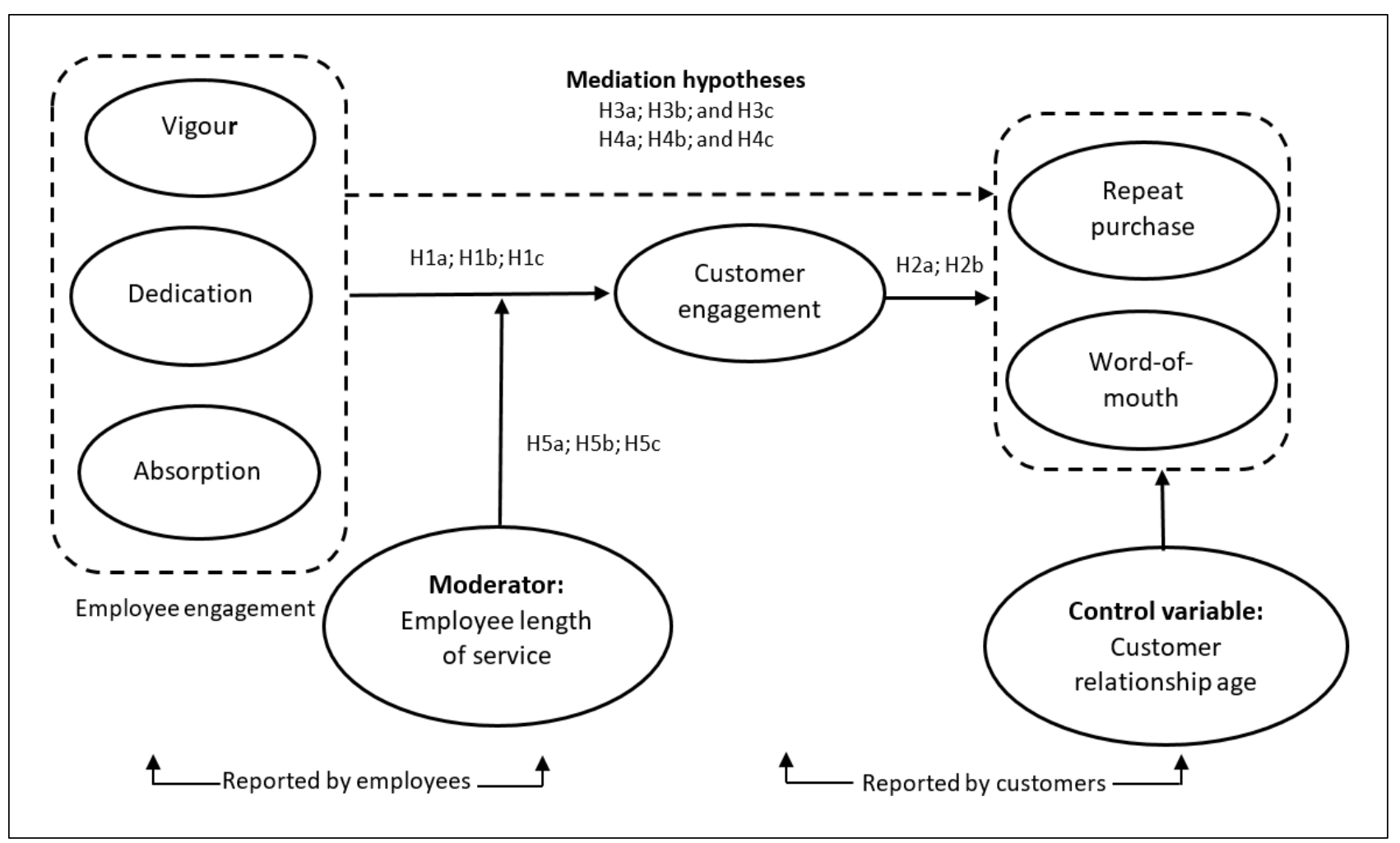


Table 1: Descriptive statistics of constructs

\begin{tabular}{|c|c|c|c|}
\hline Construct & Loading & Mean & SD \\
\hline \multicolumn{4}{|l|}{ Employee Engagement: } \\
\hline \multicolumn{4}{|l|}{ Vigour $[\alpha=0.91 ; \mathrm{CR}=0.93 ; \mathrm{AVE}=0.70]$} \\
\hline At work, I feel full of energy. & 0.86 & 5.07 & 1.17 \\
\hline In my job, I feel strong and vigorous. & 0.85 & 4.81 & 1.21 \\
\hline When I get up in the morning, I feel like going to work. & 0.81 & 4.24 & 1.30 \\
\hline I can continue working for very long periods at a time. & 0.67 & 5.02 & 1.23 \\
\hline In my job, I am mentally very resilient. & 0.68 & 5.25 & 1.13 \\
\hline At work, I always persevere, even when things do not go well. & 0.67 & 5.46 & 1.06 \\
\hline \multicolumn{4}{|l|}{ Dedication $[\alpha=0.90 ; \mathrm{CR}=0.93 ; \mathrm{AVE}=0.74]$} \\
\hline I find the work that I do full of meaning and purpose. & 0.85 & 4.50 & 1.32 \\
\hline I am enthusiastic about my job. & 0.94 & 5.01 & 1.30 \\
\hline My job inspires me. & 0.81 & 4.56 & 1.48 \\
\hline I am proud of the work I do. & 0.71 & 5.12 & 1.15 \\
\hline I find my job challenging. & 0.59 & 4.41 & 1.42 \\
\hline \multicolumn{4}{|l|}{ Absorption $[\alpha=0.86 ; \mathrm{CR}=0.93 ; \mathrm{AVE}=0.77]$} \\
\hline Time flies when I'm working. & 0.67 & 5.11 & 1.35 \\
\hline When I am working, I forget everything else around me. & 0.71 & 4.66 & 1.14 \\
\hline I feel happy when I am working intensely. & 0.97 & 5.00 & 1.29 \\
\hline I am immersed in my work. & 0.87 & 4.87 & 1.08 \\
\hline I get carried away when I'm working.* & 0.41 & 4.39 & 1.39 \\
\hline It is difficult to detach myself from my job.* & 0.44 & 3.70 & 1.41 \\
\hline \multicolumn{4}{|l|}{ Customer Engagement: } \\
\hline \multicolumn{4}{|l|}{ Conscious Attention $[\alpha=0.87 ; \mathrm{CR}=0.93 ; \mathrm{AVE}=0.82]$} \\
\hline Anything related to this store grabs my attention. & 0.87 & 4.36 & 1.55 \\
\hline I pay a lot of attention to anything about this store. & 0.88 & 4.28 & 1.54 \\
\hline I get involved to learn more about this store. & 0.80 & 3.89 & 1.75 \\
\hline \multicolumn{4}{|l|}{ Cognitive Engagement $[\alpha=0.90 ; \mathrm{CR}=0.94 ; \mathrm{AVE}=0.83]$} \\
\hline Using products of this store gets me to think about the store. & 0.91 & 4.40 & 1.58 \\
\hline I think about the store when I use its products. & 0.90 & 4.22 & 1.66 \\
\hline $\begin{array}{l}\text { Using this store's products stimulates my interest to learn } \\
\text { more about the store. }\end{array}$ & 0.75 & 4.12 & 1.62 \\
\hline \multicolumn{4}{|l|}{ Affective Engagement $[\alpha=0.92 ; \mathrm{CR}=0.95 ; \mathrm{AVE}=0.83]$} \\
\hline I feel very positive when I use this store's products. & 0.88 & 4.64 & 1.50 \\
\hline Using products from this store makes me happy. & 0.90 & 4.71 & 1.49 \\
\hline I feel good when I use products of this store. & 0.92 & 4.74 & 1.49 \\
\hline I am proud to use products of this store. & 0.71 & 4.24 & 1.58 \\
\hline $\begin{array}{l}\text { Enthused Participation }[\alpha=0.80 ; \mathrm{CR}=0.82 ; \mathrm{AVE}=0.61] \\
\text { I spend a lot of time in this store compared to other similar } \\
\text { stores. }\end{array}$ & 0.58 & 4.50 & 1.58 \\
\hline
\end{tabular}


Whenever I buy [category], I usually buy from this store. I enjoy shopping in this store.

\begin{tabular}{|c|c|c|}
\hline 0.69 & 4.65 & 1.59 \\
\hline 0.80 & 4.99 & 1.36 \\
\hline 0.83 & 4.97 & 1.18 \\
\hline 0.95 & 5.03 & 1.23 \\
\hline 0.91 & 4.82 & 1.35 \\
\hline 0.93 & 4.79 & 1.38 \\
\hline 0.88 & 4.57 & 1.37 \\
\hline -- & 3.11 & 1.59 \\
\hline
\end{tabular}

Repeat Purchase: $[\alpha=0.88 ; \mathrm{CR}=0.93 ; \mathrm{AVE}=0.88]$

I purchase from this store repeatedly.

I usually come back and buy from this store.

Word-of-Mouth: $[\alpha=0.92 ; \mathrm{CR}=0.96 ; \mathrm{AVE}=0.89]$

I say positive things about this store to others.

If somebody seeks advice with regard to a good [category] store, I recommend this store.

I encourage my friends and relatives to buy from this store

Employee Length of Service:

How long have you been with the firm as an employee (in years)?

\section{Customer Relationship Age:}

How long have you been with the firm as a customer (in years)?

Notes: $\alpha=$ Cronbach's alpha; $\mathrm{CR}=$ composite reliability; $\mathrm{SD}=$ standard deviation; $\mathrm{AVE}=$ average variance extracted; superscript * indicates that these items were not considered in the analysis due to their low factor loading. 
Table 2: Correlation matrix and psychometric properties of constructs

\begin{tabular}{lccccccccccc}
\hline Constructs & VR & DN & AN & CA & CE & AE & EP & RP & WOM & ELS C.R. Age \\
\hline Vigour (VR) & 1 & & & & & & & & & \\
Dedication (DN) & $.75^{* *}$ & 1 & & & & & & & & & \\
Absorption (AN) & $.75^{* *}$ & $.72^{* *}$ & 1 & & & & & & & & \\
Cons. Attention (CA) & $.18^{* *}$ & $.30^{* *}$ & $.24^{* *}$ & 1 & & & & & & & \\
Cognitive Eng. (CE) & $.20^{* *}$ & $.28^{* *}$ & $.28^{* *}$ & $.54^{* *}$ & 1 & & & & & & \\
Affective Eng. (AE) & $.18^{* * *}$ & $.21^{* *}$ & $.21^{* *}$ & $.57^{* *}$ & $.60^{* *}$ & 1 & & & & & \\
Ent. Participation (EP) & $.20^{* *}$ & $.23^{* *}$ & $.24^{* *}$ & $.60^{* *}$ & $.51^{* *}$ & $.59^{* *}$ & 1 & & & & \\
Repeat Purchase (RP) & $.14^{* * *}$ & $.15^{* *}$ & $.16^{* *}$ & $.42^{* *}$ & $.32^{* *}$ & $.48^{* *}$ & $.60^{* *}$ & 1 & & & \\
Word-of-mouth (WOM) & $.19^{* *}$ & $.24^{* *}$ & $.20^{* *}$ & $.62^{* *}$ & $.45^{* *}$ & $.60^{* *}$ & $.64^{* *}$ & $.58^{* *}$ & 1 & & \\
ELS & -.03 & .09 & $-.20^{* *}$ & $-.15^{* *}$ & $-.19^{* *}$ & -.13 & $-.12^{*}$ & -.01 & $-.15^{* *}$ & 1 & \\
C.R. Age & -.04 & $-.11^{*}$ & -.001 & .01 & .05 & .01 & .05 & $.12^{*}$ & -.05 & .04 & 1 \\
\hline CR & 0.93 & 0.93 & 0.93 & 0.93 & 0.94 & 0.95 & 0.82 & 0.93 & 0.96 & -- & -- \\
\hline AVE & 0.70 & 0.74 & 0.77 & 0.82 & 0.83 & 0.83 & 0.61 & 0.88 & 0.89 & -- & -- \\
\hline NR & & & & & & & & \\
\hline
\end{tabular}

Notes: Superscript $* *=p<0.01$ and $*=p<0.05$; Cons.=Conscious; Eng.=Engagement; Ent.=Enthused;

ELS=Employee length of service; C.R. Age=Customer relationship age

Table 3: Standardised coefficients, $t$-value and $t$-value of structural model

\begin{tabular}{|lcccc|}
\hline \multicolumn{1}{|c}{ Particulars } & $\boldsymbol{\beta}$-value & $\boldsymbol{t}$-value & $\boldsymbol{p}$-value & Decision \\
\hline H1a: Vigour $\rightarrow$ Customer engagement & -0.26 & -1.47 & 0.14 & Not supported \\
H1b: Dedication $\rightarrow$ Customer engagement & 0.42 & 2.09 & 0.03 & Supported \\
H1c: Absorption $\rightarrow$ Customer engagement & 0.21 & 2.03 & 0.04 & Supported \\
H2a: Customer engagement $\rightarrow$ Repeat purchase & 0.70 & 9.27 & 0.001 & Supported \\
$\begin{array}{l}\text { H2b: Customer engagement } \rightarrow \text { Word-of-mouth } \\
\text { Control variable: Customer relationship age } \rightarrow\end{array}$ & 0.84 & 10.94 & 0.001 & Supported \\
$\quad \begin{array}{l}\text { Repeat purchase } \\
\quad \begin{array}{l}\text { Customer relationship age } \rightarrow \\
\quad \text { Word-of-mouth }\end{array}\end{array}$ & -0.07 & -1.91 & 0.06 & Not significant \\
\hline
\end{tabular}

Notes: H3a, H3b, H3c and H4a, H4b, H4c are mediation hypotheses; H5a, H5b, H5c are moderation

hypotheses. These hypotheses are discussed separately. 
Table 4a: Path coefficients for low employee length of service (ELS)

\begin{tabular}{lllll}
\hline Particulars & $\boldsymbol{\beta}$-value & $\boldsymbol{t}$-value & $\boldsymbol{p}$-value & Decision \\
\hline Vigour $\rightarrow$ CE & -0.21 & -0.64 & 0.52 & Not significant \\
Dedication $\rightarrow$ CE & 0.60 & 1.31 & 0.18 & Not significant \\
Absorption $\rightarrow$ CE & -0.18 & -0.81 & 0.41 & Not significant \\
$\mathrm{CE} \rightarrow$ Repeat purchase & 0.61 & 5.55 & 0.001 & Significant \\
$\mathrm{CE} \rightarrow$ WOM & 0.81 & 6.60 & 0.001 & Significant \\
\hline
\end{tabular}

Table 4b: Path coefficients for high employee length of service (ELS)

\begin{tabular}{lllll}
\hline Particulars & $\boldsymbol{\beta}$-value & $\boldsymbol{t}$-value & $\boldsymbol{p}$-value & Decision \\
\hline Vigour $\rightarrow$ CE & -0.61 & -1.77 & 0.07 & Not significant \\
Dedication $\rightarrow$ CE & 0.56 & 1.71 & 0.08 & Not significant \\
Absorption $\rightarrow$ CE & 0.51 & 3.84 & 0.001 & Significant \\
$\mathrm{CE} \rightarrow$ Repeat purchase & 0.78 & 7.59 & 0.001 & Significant \\
$\mathrm{CE} \rightarrow$ WOM & 0.86 & 8.87 & 0.001 & Significant \\
& & & & \\
\hline
\end{tabular}

